\title{
COVID-19's reality shock for external-funding dependent emerging economies
}

\author{
Alicia García-Herrero and Elina Ribakova
}

ALICIA GARCíA-HERRERO

(alicia.garcia-herrero@ bruegel.org) is a Senior Fellow at Bruegel

ELINA RIBAKOVA (eribakova@iif.com) is a Deputy Chief Economist at the Institute of International Finance

The views and opinions expressed in this post are those of the authors and do not necessarily reflect the official policy or position of the Institute of International Finance, or any other organisation, employer or company. The authors are grateful to Suman Bery, Marek Dabrowski, Maria Demertzis, Piroska Nagy Mohacsi, Alexander Lehmann, Franceso Papadia, Mark Sobel, Brad Setser, Nicolas Véron and Guntram Wolff for useful comments.

\section{Executive summary}

COVID-19 HAS BROUGHT to light a reality that had been mostly forgotten in an era of ample dollar liquidity: the excessive dependence of emerging economies on external financing. The sudden increase in global risk aversion arising from COVID-19 has caused investors to rush to safe assets and to the dollar, away from no-reserve currencies. The COVID-19 shock has also sharply reduced emerging markets' access to dollars, exports, tourism receipts and even remittances, as the shock also affects the countries where migrants earn their incomes. The fiscal and monetary room emerging economies have to respond is limited, and the lack of automatic stabilisers on the fiscal side also means that fiscal policy does not have the same redistributive effects during a severe shock as in the developed world.

IN PRINCIPLE, VARIOUS options are available to confront liquidity problems: domestic monetary policy, capital controls, dipping into foreign exchange reserves, regional schemes such as the Chiang Mai Initiative Multilateralisation, central bank swap lines, and International Monetary Fund programmes.

BUT NOT ALL these options are available to most countries. Central banks' responses to the pandemic have been much less aggressive in the emerging world than in the west, as their currencies have plummeted in many cases, increasing the cost of dollar liabilities. Capital controls are temporary and costly. Self-insurance and regional insurance schemes are unavailable to many economies, particularly in Latin America. The United States Federal Reserve has reacted quickly with swap lines to key central banks, but this is only a partial option because the Fed risks being overburdened in its attempt to provide cross-border dollar liquidity. The IMF remains the most obvious lender of last resort for emerging economies, but needs to make two changes to become more effective: a more targeted set of facilities with quicker disbursement and less conditionality; and increased financial resources.

\section{Recommended citation}

García-Herrero, A. and E. Ribakova (2020) 'COVID-19's reality shock for external-funding dependent emerging economies', Policy Contribution 10/2020, Bruegel

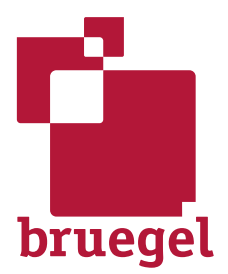




\section{Introduction}

The spread of COVID-19 to emerging economies has brought to light a reality that had been mostly forgotten in an era of ample dollar liquidity: the excessive dependence of emerging economies on external financing. This dependence, which had been a long-standing problem as shown by the large number of crises in the emerging world since the 1970s, seemed to have been overcome, for two main reasons. First, emerging economies have seen the development of domestic financial markets, denominated in local currency, which foreign investors could tap. Second, there has been a move towards inflation targeting, with the exchange rate as a welcome shock absorber.

The reality though is somewhat less positive. Fickle foreign investors have jumped into these markets, making them still very susceptible to spikes in global risk aversion. In addition, not all sectors in emerging markets have reduced their dependence on dollar borrowing, and companies have actually increased it. This means that emerging markets have not necessarily

Emerging markets have not necessarily become more resilient to a potential global dollar shortage, if anything the opposite; this is especially problematic at times of global stress become more resilient to a potential global dollar shortage, if anything the opposite. This is especially problematic at times of global stress when global risk aversion spikes lead to a flight to the reserve currency, the dollar. On the generalisation of floating exchange rate regimes (with a few exceptions), shock absorption through exchange rate depreciation is possible as long as investors trust the central bank's ability to control the slide of the currency. This is generally the case in normal times, but the current shock is so large that it will be increasingly hard for central banks in the emerging world to let their currencies float (or sink in many cases).

COVID-19 is having a massively negative impact on the global economy and emerging economies are not exempted from it. The reduced mobility stemming from lockdowns and other containing measures has severely impacted economic activity. This is even more the case for commodity exporters given the collapse in commodity prices during the pandemic. The fiscal and monetary room emerging economies have is limited. Their tax bases are limited and the lack of automatic stabilisers on the fiscal side also means that fiscal policy does not have the same redistribution effects during a severe shock as in the developed world. As for monetary policy, the room to cut rates is there, in principle, at least for countries with floating exchange regimes, but rapid currency depreciations limit their space for further action.

More importantly, emerging economies lack hard currencies and, thus, tend to depend structurally on the dollar - or other hard currency - for their external financing. This dependence is all the more relevant for countries with very low domestic savings and structural current account deficits. The sudden increase in global risk aversion has rushed investors to safe assets and to the dollar, away from no-reserve currencies. Although the United States Federal Reserve has reacted very fast, cross-border dollar liquidity has remained tight, as clearly shown by the sharp movements in cross-currency swaps for most currencies, even hard ones such as the yen and the euro. The global dollar shortage further complicates the financing of emerging markets' balance-of-payments needs.

In this Policy Contribution, we look into the factors that put emerging economies more or less at risk of a sudden reduction in dollar liquidity, as a consequence of the COVID-19 outbreak. We review the tools at their disposal to address this problem, and the roles of the Fed and the International Monetary Fund as major providers of dollar liquidity. We conclude with recommendations on the pecking order that could be followed so emerging economies can be relatively-well shielded from the dollar shortage problems related to COVID-19. 


\section{Dependence on external funding}

The degree of dependence of emerging economies on dollar liquidity stems from their economic structures and their external finances. Emerging markets depend on foreign capital and income through a number of channels (Carstens and Shin, 2019). The capital channel reflects the net borrowing through capital inflows. The more emerging markets rely on shortterm portfolio inflows or 'hot money', the more they are exposed to global dollar liquidity shortages. Emerging markets also receive dollar liquidity via the income channel, mostly via net exports of goods (including commodities) and services (notably tourism), or payments for the cross-border use of a country's endowments, which for emerging economies, tends to be labour and, thereby, remittances. The COVID-19 shock has sharply reduced emerging markets' access to dollars, exports, tourism receipts and even remittances, as the shock also affects the countries where migrants earn their income. The sudden stop in portfolio flows into emerging economies has been unprecedented. In fact, the size of portfolio outflows is several times bigger than in 2008, the 2013 'taper tantrum', or the China scare in 2015' (Figure 1).

\section{Figure 1: Accumulated non-resident portfolio flows to emerging markets since} indicated date, $\$$ billions

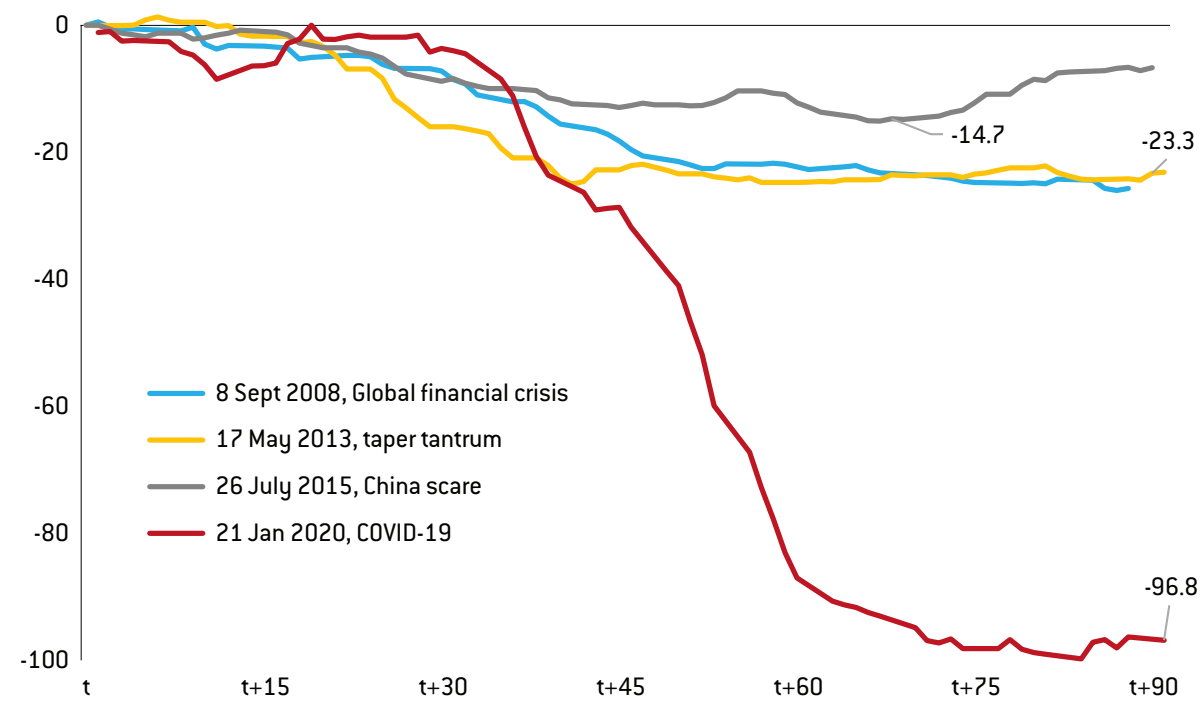

Source: Bruegel based on IIF, Natixis.

In addition to the sell-off of dollar-denominated corporate credit from emerging markets, there has also been a sudden exit of foreign investors from local-currency sovereign debt markets, which had long thought to be more resilient to global risk aversion. Furthermore, exports - especially commodity exports - have collapsed ahead of the coming global recession. Against this backdrop, the International Monetary Fund has estimated that the total gross financing need of emerging markets could be as much as $\$ 2.5$ trillion $^{2}$, with more than 100 countries already demanding financial assistance. A good part of these needs is concentrated in a few systemic emerging markets, which have long kept market access and are suffering most from the sudden stop in capital inflows. This is especially concerning in regions with large external debts. One of the most obvious cases is Latin America (Figure 2).

1 The taper tantrum refers to the episode of sharp capital outflows from emerging markets when the Fed signalled a desire to taper the degree of monetary stimulus. Another shock to capital flows to emerging markets was triggered in 2015 by devaluation pressure on the remimbi amid sharp capital outflows from China.

2 See https://www.imf.org/en/News/Articles/2020/04/03/tr040120-transcript-background-briefing-conference-call-imf-resources-strategy-help-combat-covid-19. 


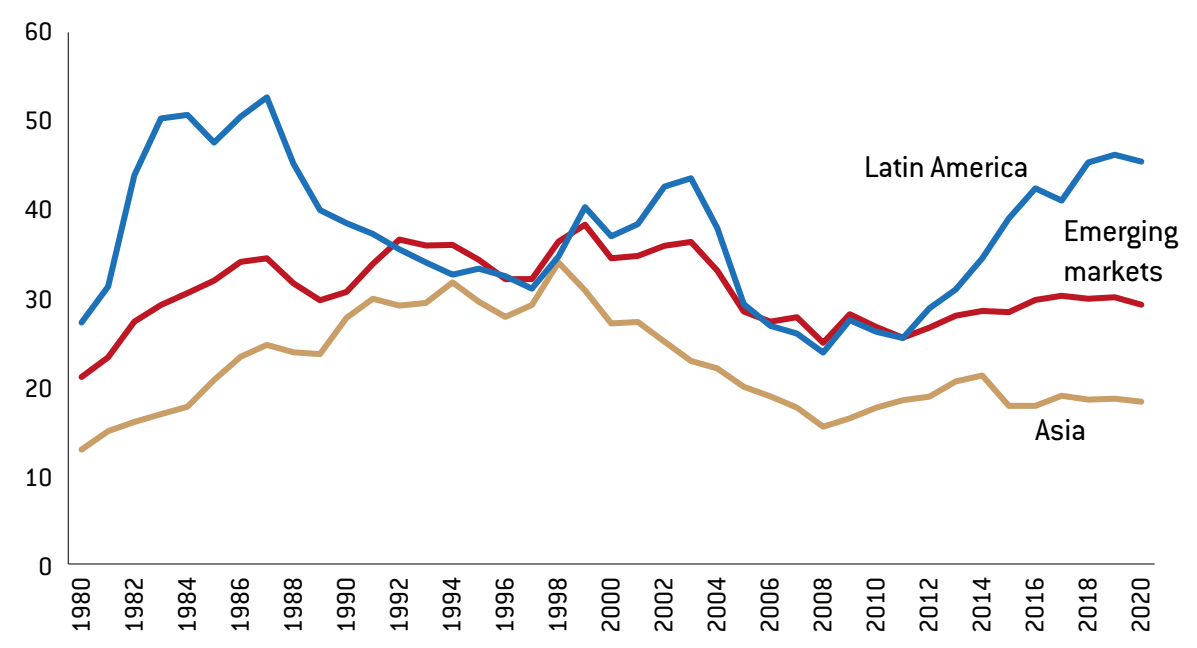

Source: Bruegel based on IIF, Natixis.

What tools can emerging markets count on to address this challenge? We review the different options, from the independent use of monetary policy to capital controls, to regional arrangements for insurance and potential access to the Fed's generation of hard currency or borrowing from the International Monetary Fund.

It should be stressed that we focus on liquidity and not solvency problems, but we acknowledge that the line between solvency and liquidity will become less clear than ever because of the impact of COVID-19 on emerging-market economies. Furthermore, illiquidity left unaddressed for an extended period might push countries into a solvency crisis - which might already be happening in borderline cases.

\section{How to respond?}

\section{Solution 1: Domestic policies}

The first and most obvious line of defence for a country is to use its own monetary policy to stimulate the economy. This might be relatively easy for a developed economy with a hard currency and a flexible exchange regime, but is much less so for emerging economies, especially for those that are highly dependent on external financing.

Central banks in the emerging world have generally managed to follow the Fed's monetary policy easing in response to the COVID-19 outbreak, but this might prove much harder in the future for those countries with large dollar liabilities. It should also be noted that big companies, which have tapped dollar markets in the last few years, are the first to suffer from sharp balance sheet effects because their income continues to be mainly drawn from their home markets or from their commodity exports.

The ability of central banks to continue to use monetary policy independently, however, is capped by investors' willingness to accept currencies that have depreciated extensively and might not have reached the bottom (Figure 3). The fact that the third wave of COVID-19 is concentrated in the emerging world does not help improve investors' perceptions of what might come next. This offers very little room for central banks to cut rates to support the economy. In some cases monetary policies in the countries most dependent on external financing could end up being pro-cyclical, as interest rates need to be raised to keep capital coming in. 
Figure 3: Worst-performing emerging market currencies against the dollar, \%, from 1 March 2020

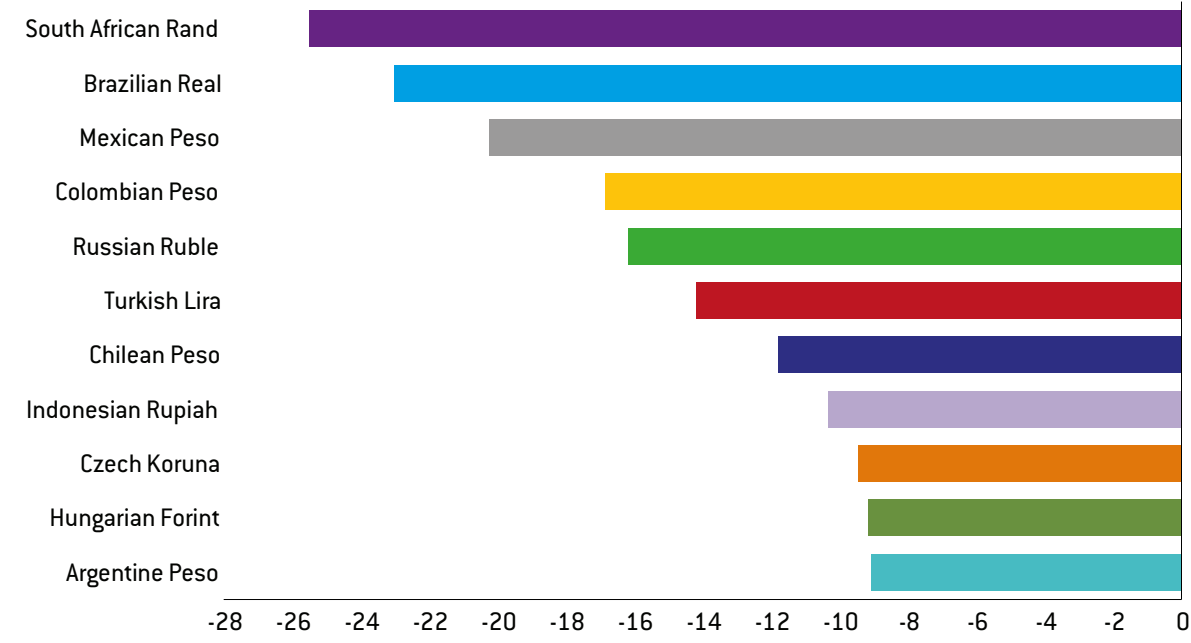

Source: Bruegel based on Bloomberg, Natixis

\section{Solution 2: Capital controls}

The obvious short cut to avoid a vicious circle of rate hikes needed to stem capital outflows is capital controls. These used to be anathema under the Washington Consensus framework, but have been reconsidered during the past few years, especially since the global financial crisis. The main argument for some form of capital flow management measures is the increasingly deep financial integration of emerging economies with the rest of the world, which turns the well-known trilemma of maintaining an independent monetary policy, a flexible exchange rate regime and an open capital account, into a dilemma. This reality, according to Rey (2013), calls for the use of macroprudential policies and, if needed, some capital controls.

It seems clear that the massive impact of COVID-19 on emerging markets' external financing will probably accelerate the trend towards a more positive view about capital controls. The obvious place where we could see that change would be the IMF's integrated policy framework, which the institution announced in early $2020^{3}$ but has not yet finalised. In any event, there is an undeniable cost associated with introducing capital controls. Those emerging economies with market access could lose it. Opting for capital controls for countries which are still able to cover at least part of their financial needs in the market does not seem to be the right way to go ${ }^{4}$.

\section{Solution 3: Self-insurance}

Barring the use of strict capital controls, which could keep emerging economies cut off from international financing, other tools are needed to address the negative impact of COVID-19 on external funding. The two most obvious lines of defence which have been built up over time are: i) self-insurance through the accumulation of foreign exchange reserves, and ii) regional insurance schemes.

Only a few emerging economies can safely claim that their reserves are massive enough to deal with the shock. Most importantly, reserves tend to be concentrated in two main regions, Asia and the Middle East, with more than half of the some $\$ 22$ trillion in forex reserves globally held by central banks and sovereign wealth funds.

3 Kristalina Georgieva, 'IMF chief: we are rethinking our advice to emerging markets', Financial Times, 18 February 2020, see https://www.ft.com/content/b53468f0-4e46-11ea-95a0-43d18ec715f5.

4 Notwithstanding the degree of global dollar shortage, Indonesia, Phillipines, United Arab Emirates and Qatar, among others, tapped the market in April 2020 with strong investor interest. 
Low oil prices and commitments to production cuts mean that oil producers in the Middle East will have to draw down their forex reserves. As for Asia, the lack of external demand from the rest of the world should also reduce their current-account balances, probably dragging down reserves although quite likely to a lesser degree than in the Middle East. It should be noted that this process has already started, after oil prices peaked in 2014. Even in Asia, current-account surpluses have been shrinking since 2011, while the size of these economies has continued to grow relentlessly (Figure 4). This means the role for self-insurance (measured by the size of forex reserves to GDP) is more limited today, even in Asia (Figure 5). More generally, the extensive use of self-insurance does not seem an option for other emerging market regions, not even for all countries within Asia or the Middle East. For Latin America or Africa, high dependence on external funding seems much harder to address because external debt is much larger, and the terms of trade more volatile.

Figure 4: Foreign reserves, $\$$ trillions

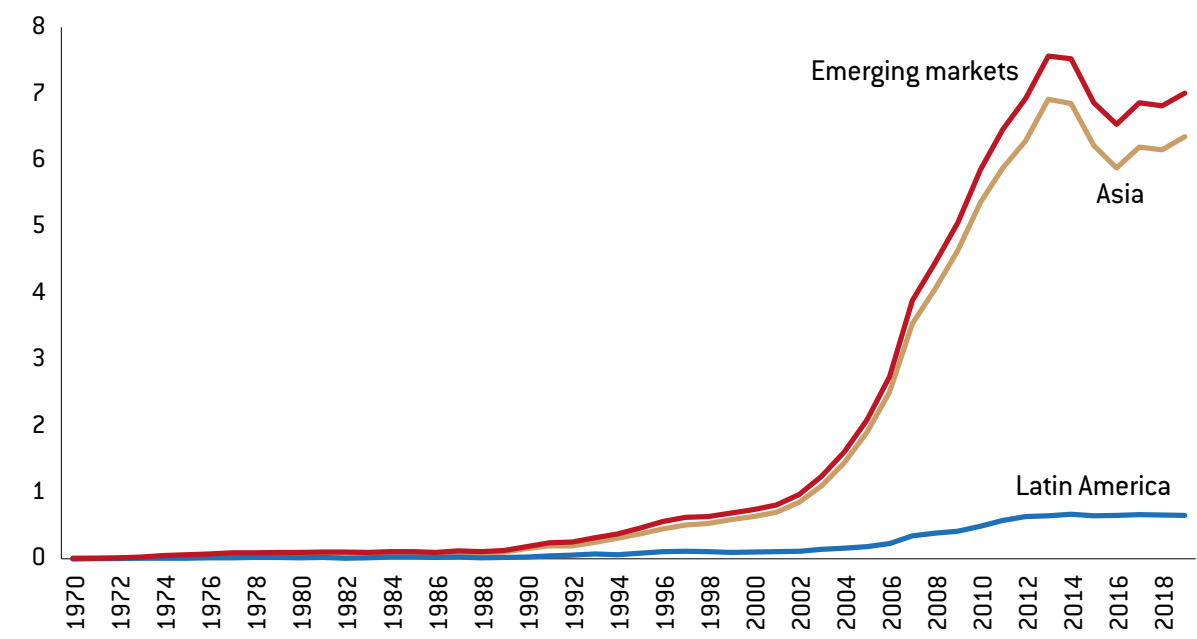

Source: Bruegel based on IIF, Natixis.

Figure 5: Foreign reserves, \% GDP

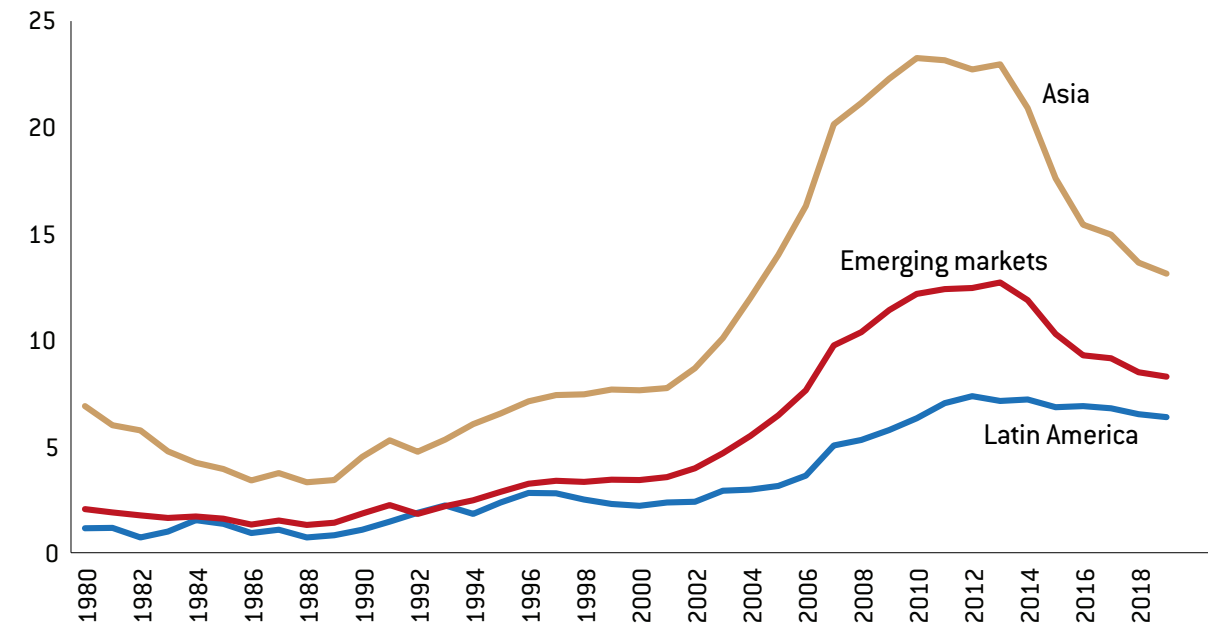

Source: Bruegel based on IIF, Natixis. 


\section{Solution 4: Regional insurance}

On regional insurance schemes, there are major differences between regions. The most developed scheme has been created in Asia, under the aegis of the ASEAN $+3^{5}$. The so-called Chiang Mai Initiative, which started as a spaghetti bowl of bilateral swap lines built since the 1997 Asian financial crisis, was increasingly multilateralised after 2009, reflected in its new name, Chiang Mai Initiative Multilateralisation (CMIM). The reason for this was the fear of the potentially devastating effects of the 2008 global financial crisis on the region. Since then, the amount of foreign reserves pooled has increased up to $\$ 240$ billion to address balance-of-payments and short-term liquidity difficulties. It should be noted, though, that even with CMIM - the most advanced case of regional insurance - the use of reserves by a specific member is subject to IMF conditionality 6 .

Beyond, CMIM, very few regional mechanisms exist. The second most obvious is The Latin American Reserves Fund (FLAR), which started with reserve pooling for a number of Andean economies in 1991 but which has fallen short of expectations in terms of the size of the reserves pool and the number of countries included. A deeper multilateralisation of FLAR is long overdue and certainly necessary for a region that has less self-insurance than Asia, in terms of forex reserves, but much bigger external financial needs (Figures 6 and 7) ${ }^{7}$.

\section{Figure 6: Regional financing arrangement capacity [ $\$$ billions]}

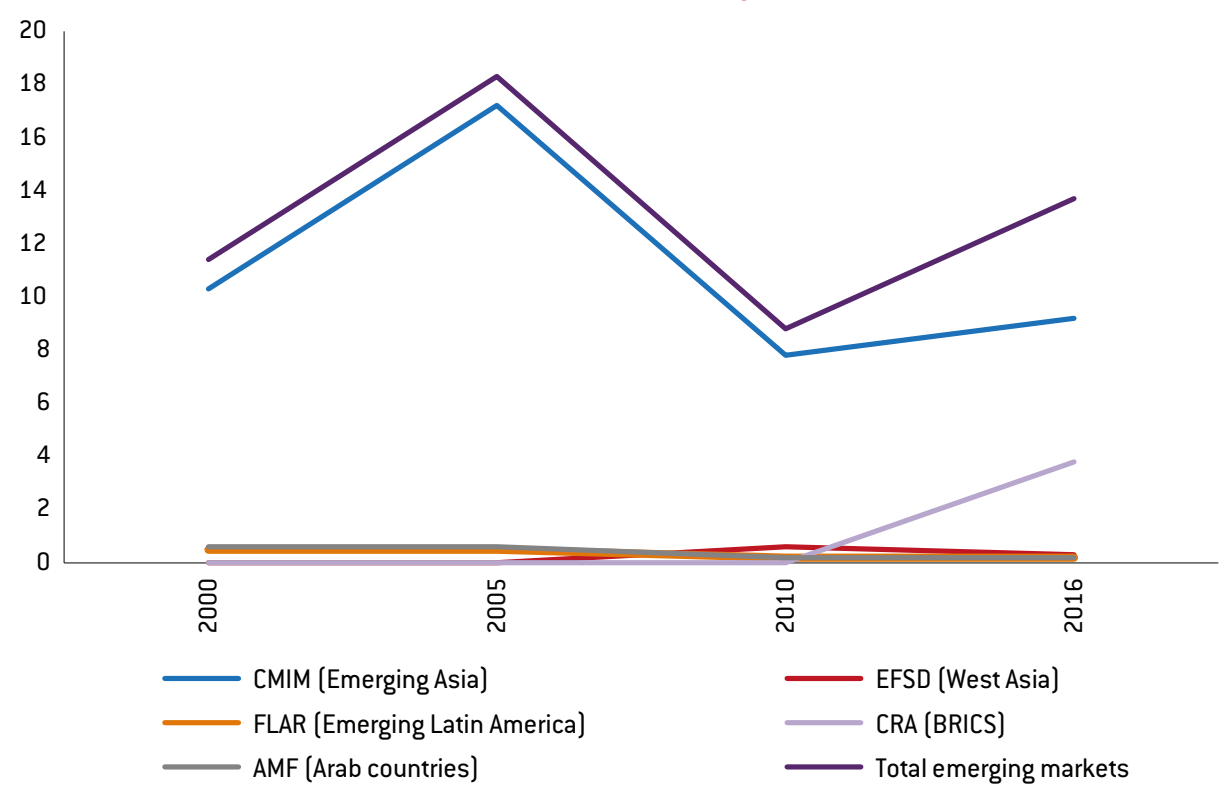

Source: Bruegel based on IMF, Natixis. Note: The regional financing arrangements are: Chiang Mai Multilateral Initiative (CMIM), BRICS Contingent Reserve Arrangement (CRA), Eurasian Fund of Stabilisation and Development (EFSD), Fondo Latinoamericano de Reservas (FLAR), Arab Monetary Fund (AMF)

Another interesting example, though very different in nature, is the Vienna Initiative ${ }^{8}$, started in 2009 by public and private European stakeholders. The key was the combination of policy coordination and financing, with 'cross conditionality.' Countries with strong policies could secure IMF/EU programme funding, while foreign banks were incentivised to keep liquidity in the host country because they could obtain financial support from the investing

5 Ten ASEAN members plus China, Japan and Korea.

6 The de-linking from IMF conditionality has been pursued but not yet achieved, or at least not fully. Still, only $30 \%$ of the maximum amount that each country can withdrawal from the pool can be accessed without IMF conditionality.

7 A report by an expert group (Informe del grupo de trabajo sobre estabilidad financiera regional, 2019) calls for urgent reform of FLAR to make it a truly multilateral and larger pool of reserves for a greater number of Latin American countries.

8 See https://www.eib.org/attachments/efs/10years_vienna_initiative_en.pdf. 
international financial institutions ${ }^{9}$. The Vienna Initiative's objective was much less preemptive than traditional reserve pooling and much more geared towards solving an existing problem. In fact, in the context of an impending credit crunch at the time, the initiative aimed at EU-based cross-border banks operating in emerging Europe, to keep credit flowing into those economies and to dissuade them from drawing their liquidity back to the headquarters. Over time, the Vienna Initiative has evolved into a permanent platform for analysis and cooperation. Still, it only focuses on bank flows, while countries in the region have heavily increased their reliance on bond markets and, thus, portfolio flows.

Figure 7: Regional financing arrangement capacity in emerging economies [\%]

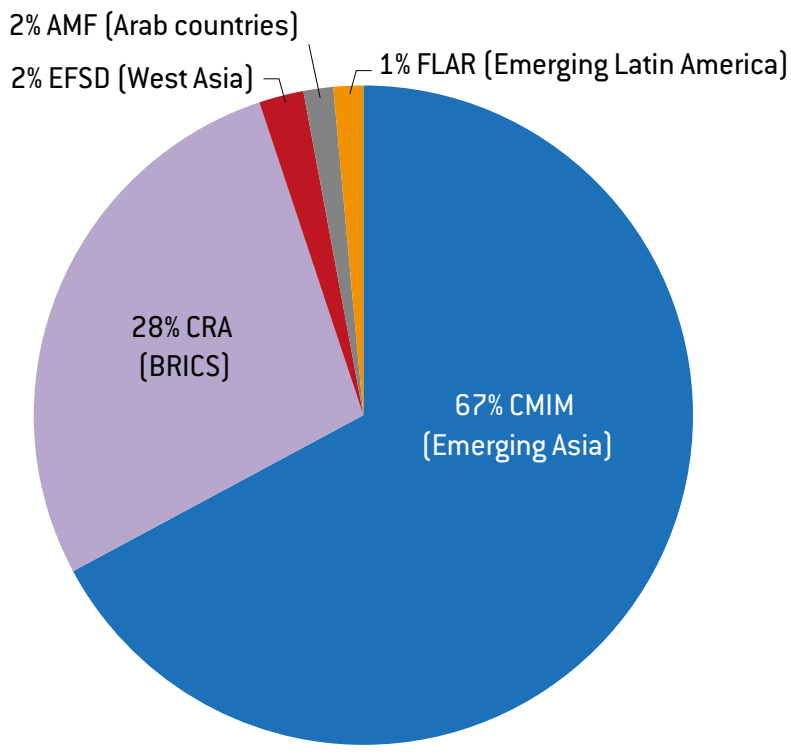

Source: Bruegel based on IMF, Natixis. Note: See note to Figure 6 .

\section{Solution 5: Central bank cross-border liquidity}

After some hesitation, the 2008 global financial crisis opened the door for the Fed to offer limited but relevant support for central banks in needed of dollar liquidity. The sudden episode of global liquidity shortage in March 2020 as a consequence of the COVID-19 market collapse has pushed the Fed to react much more quickly than in 2008.

The first step taken by the Fed was to re-activate on and improve the financial conditions of its swap lines with those central banks with which it has had standing swap arrangements since the global financial crisis (Bank of Canada, Bank of England, Bank of Japan, European Central Bank and Swiss National Bank). Access to the swap lines was made cheaper, with longer durations and, in some cases, such as the Bank of Japan, with a bigger quota. Just days after this first action, and in sharp contrast to the several months it took the Fed to take this very same decision during the global financial crisis, swap lines were extended to a further four central banks. It should be noted that only two of the central banks are from emerging economies, Brazil and Mexico, with two additional cases - South Korea and Singapore depending on how emerging markets are defined (Table 1). Overall, at time of writing, the use of such lines by emerging markets has remained rather limited ${ }^{10}$. It is unclear whether this is because there has not been a need, or if recipient central banks fear being stigmatised by market participants if such lines were to be used more massively.

Following the Fed's very rapid response, the European Central Bank has also started to offer cross-border liquidity outside of the euro area. At time of writing, Bulgaria and Croatia

9 The European Bank for Reconstruction and Development, European Investment Bank and the World Bank Group. 10 See https://apps.newyorkfed.org/markets/autorates/fxswap. 
Table 1: Swap lines granted by the Fed since March 2020

\begin{tabular}{|c|c|c|c|c|c|c|}
\hline \multicolumn{7}{|c|}{ Central banks in emerging markets } \\
\hline Central bank & $\begin{array}{l}\text { Approved \$ swap } \\
\text { line size with Fed } \\
\quad \text { (\$ billions) }\end{array}$ & $\begin{array}{l}\text { Swap line as } \\
\text { share of short- } \\
\text { term external } \\
\text { debt }(\%)\end{array}$ & $\begin{array}{l}\text { Short-term } \\
\text { external debt as } \\
\text { share of forex } \\
\text { reserves }(\%)\end{array}$ & $\begin{array}{l}\text { Forex } \\
\text { reserves } \\
(\$ \\
\text { billions })\end{array}$ & $\begin{array}{c}\text { Announcement } \\
\text { date }\end{array}$ & Type \\
\hline $\begin{array}{l}\text { Banco Central do } \\
\text { Brasil }\end{array}$ & 60 & 75.9 & 23 & 333 & March 19, 2020 & Temporary \\
\hline Bank of Korea & 60 & 44.8 & 34 & 389 & March 19, 2020 & Temporary \\
\hline Banco de Mexico & 60 & 90.9 & 37 & 175 & March 19, 2020 & Temporary \\
\hline $\begin{array}{l}\text { Monetary } \\
\text { Authority of } \\
\text { Singapore }\end{array}$ & 6 & 0.5 & 403 & 276 & March 19, 2020 & Temporary \\
\hline \multicolumn{7}{|c|}{ Central banks in developed markets } \\
\hline Bank of Canada & 90 & 12.7 & 942 & 75 & Permanent* & Permanent \\
\hline Bank of England & 90 & 1.6 & 3962 & 139 & Permanent* & Permanent \\
\hline Bank of Japan & 90 & 3 & 228 & 1297 & Permanent* & Permanent \\
\hline $\begin{array}{l}\text { European Central } \\
\text { Bank }\end{array}$ & 90 & 0.8 & 3704 & 295 & Permanent* & Permanent \\
\hline $\begin{array}{l}\text { Swiss National } \\
\text { Bank }\end{array}$ & 90 & 9 & 126 & 795 & Permanent* & Permanent \\
\hline $\begin{array}{l}\text { Danmarks } \\
\text { National Bank } \\
\text { (Denmark) }\end{array}$ & 30 & 15.5 & 334 & 58 & March 19, 2020 & Temporary \\
\hline $\begin{array}{l}\text { Norges Bank } \\
\text { (Norway) }\end{array}$ & 30 & 13.1 & 331 & 69 & March 19, 2020 & Temporary \\
\hline $\begin{array}{l}\text { Sveriges Riksbank } \\
\text { (Sweden) }\end{array}$ & 60 & 21.3 & 626 & 45 & March 19, 2020 & Temporary \\
\hline $\begin{array}{l}\text { Reserve Bank of } \\
\text { Australia }\end{array}$ & 60 & 18 & 708 & 47 & March 19, 2020 & Temporary \\
\hline $\begin{array}{l}\text { Reserve Bank of } \\
\text { New Zealand }\end{array}$ & 30 & 50 & 333 & 18 & March 19, 2020 & Temporary \\
\hline
\end{tabular}

* These central banks have agreed to lower the pricing on the standing US dollar liquidity swap arrangements by 25 basis points. In addition, they have also agreed to begin offering US dollars weekly in each jurisdiction with an 84-day maturity, in addition to the 1-week maturity operations previously offered. These changes took effect from 16 March 2020.

had secured swap lines with the $\mathrm{ECB}^{11}$.

Beyond swap lines, in April 2020, the Fed stepped up its support for a well-functioning dollar market overseas by opening a repo facility for a large number of central banks. This measure has a secondary, but certainly important role, by reducing the risks of a sell-off of US Treasuries by central banks trying to access dollar liquidity. In fact, US Treasuries can be used to pledge dollar liquidity through the Fed's repo line without the need to sell them. It should be noted, though, that this repo line is not targeted at any particular central bank, and collateral is needed to borrow, making it a clearly inferior option compared to a swap line, which is only available to very few central banks ${ }^{12}$. In fact, some central banks, such as Bank Indonesia and, to a lesser extent, the Hong Kong Monetary Authority, have communicated extensively on access to the repo facility as a way to calm markets about a potential scarcity of dollars in the future.

11 See https://www.ecb.europa.eu/press/pr/date/2020/html/ecb.pr200422 962a743486.en.html and https://www.ecb. europa.eu/press/pr/date/2020/html/ecb.pr200415_1 92fe0267b1.en.html.

12 See https://www.federalreserve.gov/newsevents/pressreleases/monetary20200331a.htm. 


The IMF should
take centre stage in
helping emerging
economies deal
with a global dollar
shortage. However,
two key constraints
are becoming
increasingly obvious.

While the Fed's faster reaction this time has been welcomed by the market, as clearly shown by cross-currency swap spreads coming down aggressively after such announcements, the Fed's role in the provision of dollar global liquidity should not be overestimated. Bilateral swap lines are limited in size and withdrawals from the repo line hinge on having US Treasuries to pledge and, therefore, are not a substitute of self-insurance mechanisms. A central bank with limited forex reserves cannot really count on the Fed to solve its problems. There is no such thing as a multiplier of dollar liquidity. Furthermore, the Fed is already having to deal with a rapidly expanding balance sheet for domestic reasons, which will further restrict the Fed in expanding liquidity overseas. All in all, the Fed - the ultimate guarantor of the value of the reserve currency - currently risks been overburdened, meaning that can be expected to play only a limited role in cross-border liquidity.

\section{Solution 6: The International Monetary Fund}

The IMF, long considered the undisputable lender of last resort for emerging markets, should indeed take centre stage in helping emerging economies deal with a global dollar shortage. However, two key constraints are becoming increasingly obvious. The first relates to the IMF's existing set of programmes for responding, quickly and forcefully, to a financing constraint in hard currency. The second goes beyond the design of IMF programmes to the constraints in its lending capacity.

Since the pandemic outbreak, as many as 100 countries, and counting, have asked for IMF financial assistance. The Fund has stepped up efforts to review its facilities, and in particular, those geared towards addressing hard-currency liquidity constraints.

The IMF currently provides three liquidity facilities, two already existing (Flexible Credit Line and Precautionary Liquidity Line), and the new Short-Term Liquidity Facility. The Flexible Credit Line (FCL), unlimited in terms of size of access but based on stringent pre-qualification criteria, was set up in 2009. The Precautionary Liquidity Line (PLL), introduced in $2011^{13}$, has strong pre-qualification criteria and some ex-post conditionality, and is rather limited in size. So far, the use of such liquidity facilities has been rather limited. Only five countries have been granted access to the FCL (Chile, Columbia, Mexico, Peru and Poland) and one has asked for the PLL (Morocco).

Aware of the limitations of its toolkit for liquidity issues, the IMF proposed the creation of a new facility in 2017. This was approved during the April 2020 Spring Meetings -the ShortTerm Liquidity Facility (SLL). It is, however, still rather limited in size at 145 percent of quota, especially for systemically important economies, whose access to international markets is so much bigger than their IMF quotas and could suddenly be curtailed.

The IMF is also ramping up the extension of its fast-disbursement support to deal with the impact of the COVID-19 crisis through the Rapid Financing Instrument (RFI) and the concessional Rapid Credit Facility (RCF). The RCF is interest-free and available to low-income countries only. Beyond the speed of disbursement, which is welcome, these facilities are also very limited in size at each country's level (100 percent of quota). Their overall limit is only $\$ 100$ billion. It seems clear that these rapid facilities provide no real respite from external financing concerns for systemically important economies with market access. There is an important difference, however, between FCL/PLL/SLL, which are largely ex-ante precautionary support, and RFI/RCF, which involve actual disbursements with little or low conditionality.

Furthermore, although quick, access is not guaranteed because a public debt sustainability analysis is a pre-condition for withdrawal. In other words, debt dynamics need to be sustainable or on track to be sustainable. Expecting debt sustainability after including the impact of COVID-19 on growth and debt projections might be unrealistic. There have been calls urging the Fund to relax the requirement for COVID-19-related programmes (Rediker and Crebo-Rediker, 2020). Other than RFI and RCF, the IMF offers other lending programmes which, however, are slower to disburse or require even more conditionality, making them

13 See https://www.imf.org/en/News/Articles/2015/09/14/01/49/pr11424. 
inadequate to address a country's sudden worsening of external financing.

All in all, existing facilities - including the newly approved SLL - do not seem to fully cover the sudden increase in external financial needs of IMF members, especially for systemically-important countries with access to international capital markets.

Beyond the suitability of the IMF's toolkit, which can clearly be improved beyond recent efforts, the key outstanding question is whether the IMF has enough financial resources for the pressing needs of a large part of its members, which cannot be categorised as low-income countries. The IMF's available resources are currently estimated at just under $\$ 800$ billion, as about one fifth of its total lending capacity of $\$ 1$ trillion, is already committed to existing programmes $^{14}$.

A cursory look at IMF resources illustrates the difficulty in increasing them. First and foremost, quotas account for 65 percent of the total ( $\$ 651$ billion). The New Arrangements to Borrow (NAB) follows, with $\$ 250$ billion. In January 2020, the IMF's Executive Board approved a doubling of NAB resources to $\$ 500$ billion, for a period from 2021 to $2025^{15}$ (at time of writing, this still needs the consent of all creditors). Finally, the last category of resource is the Bilateral Arrangements to Borrow (BBs), which currently stand at $\$ 434$ billion. Existing BBs end this year, but new BBs were agreed in March 2020 up to 2023. While quotas may equal $\$ 651$ billion, the 'forward commitment capacity' is around $\$ 285$ billion as some of the money is already committed to existing lending programmes, and some of the quotas come from countries that are themselves borrowers from the IMF.

An overall quota increase for the IMF would be desirable to garner more resources and improve the composition of financing - a large share of the IMF's funding will come from a pool not requiring additional rolling approvals. Ultimately a quota increase will be needed, including to address voting power issues. However, it is not a quick solution.

\section{Figure 8: IMF quota shares by country/region}

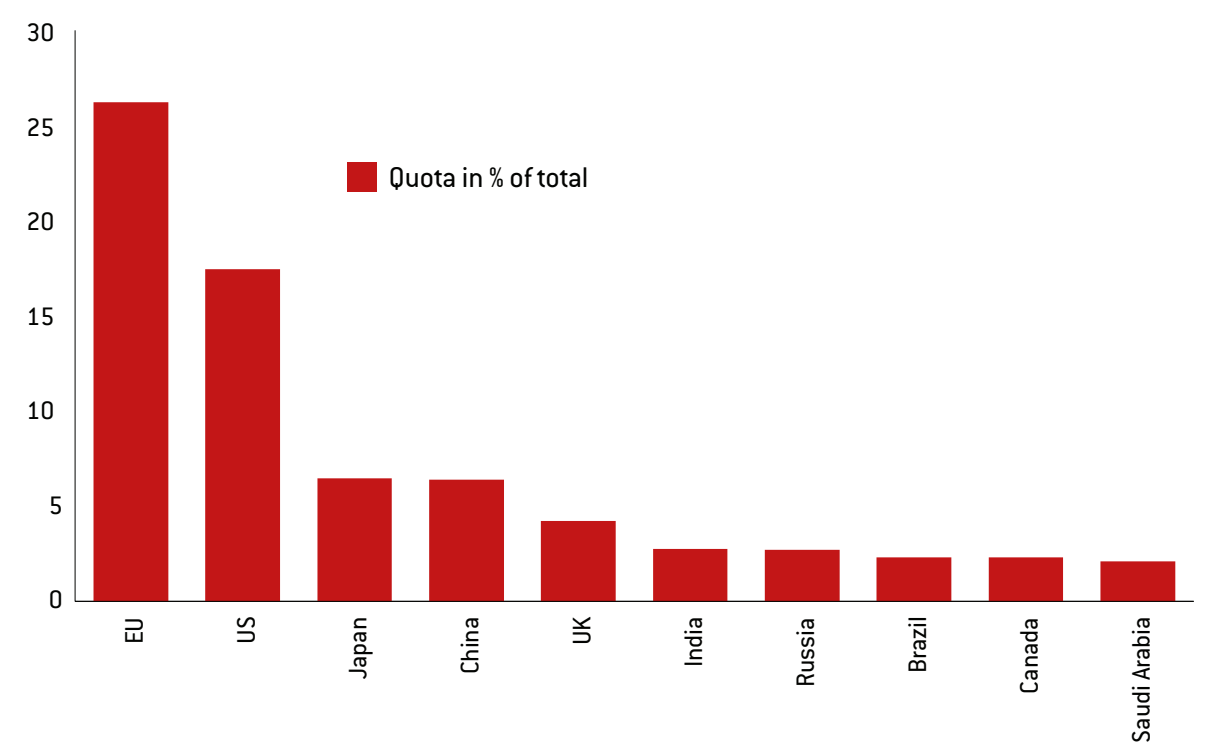

Source: IMF.

A possibility of a new increase in Special Drawing Rights (SDR) of as much as $\$ 500$ billion or even $\$ 1$ trillion has been suggested (Mühlich et al, 2020). A clear benefit of the proposal would be that, once approved, it can get foreign exchange to emerging countries quickly and free of conditionality. However, this does not seem easily achievable because an 85

14 See https://www.imf.org/external/np/tre/activity/2020/041720.pdf.

15 See https://www.imf.org/en/About/Factsheets/Where-the-IMF-Gets-Its-Money. 
percent majority of IMF shareholders is needed and the US has already refused to support the increase ${ }^{16}$. SDR would be allocated according to the IMF quota, with the US, Europe and China getting the largest shares. Developed economies account for over 60 percent of the IMF quotas (Figure 8), which means that only 40 percent, at most, would be geared towards the emerging world and, even less if we consider that China is unlikely to need IMF funding. Still, small economies might benefit from a conditionality-free boost to reserves and have greater access to other facilities. A higher quota also means that countries can qualify for more support as most of the IMF programme limits are denominated in percent of quota. Nevertheless, an SDR allocation seems unlikely. IMF Managing Director Kristalina Georgieva in April 2020 suggested that the IMF is considering a re-allocation of SDR from developed to frontier markets ${ }^{17}$. While these grand solutions in terms of SDR increases and even reallocation are welcome, they do not look immediate, while the negative consequences of COVID-19 are.

\section{Conclusions}

COVID-19 is by far the biggest challenge policymakers in emerging economies have had to deal with in recent history. Beyond the potentially large negative impact on these countries' fiscal accounts, and the related solvency issues, worsening conditions for these countries' external funding are a major challenge. This has been made even harder by the sharp increase in global risk aversion since March 2020, leading to a global dollar shortage and resulting in a sudden stop in capital flows into emerging economies. Other sources of dollar inflows (exports, tourism, and remittances) are also plummeting.

Emerging economies have a number of potential policy options but the reality is that these are generally not available to most countries. The first, and most obvious, is a country's own policy space, but this tends to be limited. Central banks' responses to the pandemic have been much less aggressive in the emerging world than in the west, as their currencies have plummeted in many cases, increasing the cost of dollar liabilities.

A second option, introducing capital controls, could provide temporary relief but is costly insofar as it can limit the market access that many systemically important emerging economies still have. Self-insurance and regional insurance schemes are options for a select few, mainly in Asia. Russia and the the Middle East are already resorting to this option, but questions remain about the extent and depth of the shock. Others, Latin America in particular, have much less room for self, or regional, insurance, and are in a weaker starting position to deal with COVID-19.

The Fed has been much faster to react to the dollar needs of major central banks globally than during the global financial crisis, but it seems unlikely that it can play an even bigger role compared to what it has done already. Its balance sheet is ballooning as a result of the collapse of the US economy, so increasing it to account for additional cross-border liquidity lines seems unlikely. Other central banks in the developed world, including the ECB, have been much more timid in their provision of cross-border liquidity.

Finally, the IMF continues to be the most obvious - albeit constrained - lender of last resort for emerging economies' external financing needs. Two changes are urgently needed for the Fund to be more effective. First, a more targeted set of facilities with quicker disbursement and less conditionality is urgently needed. The SLL is a welcome step but the financing that countries can receive is simply too limited for the size of the shock. Increasing the SLL limits seems wise but it might not be enough and the IMF will probably need to come up

16 See https://www.ft.com/content/9cb75566-bfd2-4f25-81f7-55780ebdaa3d.

17 See https://www.atlanticcouncil.org/commentary/transcript/imf-managing-director-kristalina-georgieva-a-conversation-on-the-global-economic-crisis/. 
with a faster solution (also in terms of conditionality). Second, no matter how much the IMF facilities are improved, addressing the financial needs of more than 100 countries implies increasing the IMF's existing financial resources. The much discussed new SDR allocation is highly relevant and sorely needed but, unfortunately, it will not happen quickly, especially if accompanied by a reallocation of SDR rights from developed to emerging economies. Against this backdrop, temporary - but faster - solutions need to be found, such as the approval of the overall $\$ 500$ billion in NAB by individual creditors so that it can be disbursed. Second, a rethink of the timeline for BBs is also warranted. The quota increase should still be pursued as a more structural solution, but without forgetting the urgency of finding other faster responses.

All in all, any country without the necessary self or regional insurance, and with great uncertainty about its external funding, should start queuing at the IMF's door, though that waiting time might be better spent on pushing the arguments we have summarised at G20 meetings. More funding in two years does not solve the problem, so second-best options must be considered for such exceptional times.

\section{References}

Carstens, A., and H.S. Shin (2019) 'Emerging Markets Aren't Out of the Woods Yet', Foreign Affairs, 15 March, available at https://www.foreignaffairs.com/articles/2019-03-15/emerging-markets-arentout-woods-yet

Informe del grupo de trabajo sobre estabilidad financiera regional (2019) Hacia un FLAR de Alcance Regional, available at https://flar.net/wp-content/uploads/2020/01/Un-FLAR-de-alcance-regionalWeb.pdf

Mühlich, L., B. Fritz, W.N. Kring and K.P. Gallagher (2020) 'The Global Financial Safety Net Tracker: Lessons for the COVID-19 Crisis from a New Interactive Dataset', GEGI Policy Brief 010, Boston University Global Development Policy Center

Rediker, D.A., and H. Crebo-Rediker (2020) 'COVID-19 uncertainty and the IMF', Future Development, Brookings Institution, 14 April, available at https://www.brookings.edu/blog/futuredevelopment/2020/04/14/covid-19-uncertainty-and-the-imf/

Rey, H. (2013) 'Dilemma not Trilemma: The global financial cycle and monetary policy independence', $V O X, 31$ August, available at https://voxeu.org/article/dilemma-not-trilemma-global-financial-cycleand-monetary-policy-independence 